\title{
Association between growth rates, age at first calving and subsequent fertility, milk production and survival in Holstein-Friesian heifers
}

\author{
Jessica S. Cooke, Zhangrui Cheng, Nicola E. Bourne, D. Claire Wathes*
}

Royal Veterinary College, Hatfield, UK; ${ }^{*}$ Corresponding Author: dcwathes@rvc.ac.uk

Received 10 October 2012; revised 11 November 2012; accepted 22 November 2012

\section{ABSTRACT}

Age at first calving (AFC) affects the profitability of dairy enterprises. This study examined the relationships between AFC and subsequent fertility, milk production and survival up to third calving in UK Holstein-Friesian heifers; Study 1 comprised 134 consecutively born heifers from the same herd (AFC $764 \pm 8$ days) and Study 2 contained 445 heifers born on 17 farms (AFC 796 \pm 6 days). Growth rates and fertility during rearing were monitored and animals were subsequently divided into four AFC groups for analysis: <23 months, 23 - 25 months, 26 - 30 months and $>\mathbf{3 0}$ months. The actual AFC reflected both growth rate and heifer fertility, with later calving heifers already lighter by 6 months of age. The proportion conceiving to first service was highest (93\% and $84 \%$ for Studies 1 and 2, respectively) for the youngest AFC group. Fertility in the first lactation was best in cows calving at $23-25$ months and worst in the oldest AFC group. Milk production parameters in the first and second lactations were broadly similar between AFC groups but significantly more heifers with an AFC $<26$ months calved for a third time. These younger calving animals therefore achieved more days in milk over 5 years, with $>44 \%$ of their days alive spent in milk production compared with only $18 \%-40 \%$ in cows calving at $\geq 26$ months. Hence cows with an AFC $<26$ months produced the most milk in their first 5 years of life. These results indicate that an AFC of $<26$ months required both a growth rate $>0.75 \mathrm{~kg} / \mathrm{d}$ up to 15 months and good heifer fertility and resulted in the best subsequent performance.

Keywords: Age at First Calving; Heifer; Fertility; Milk Production; Longevity

\section{INTRODUCTION}

Rearing replacement heifers requires a large financial outlay, with no returns until the animals enter the milking herd; heifers do not normally become profitable until their second lactation. An earlier age at first calving (AFC) can reduce rearing costs due to decreased feed, labour and building costs. A previous economic analysis showed that reducing AFC from 25 to 24 or 21 months decreased replacement costs by $4.3 \%$ or $18 \%$ respectively [1]. Conversely increasing AFC to 29 months increased replacement costs by $14 \%$. An increased AFC requires herds to keep more replacement heifers in order to maintain herd size, whilst reducing AFC allows surplus heifers to be sold, maximising herd profitability [1].

Rearing heifers to join the herd at an age and body weight (BW) that will enable them to achieve their full lifetime potential, in terms of both yield and longevity, is also fundamental. Gestation length is fixed; therefore AFC is a function of the age at the commencement of first breeding, combined with the reproductive efficiency of the animal. The decision on when to start breeding is primarily a management one. It is usually based mainly on the age of the heifer, but is also influenced by nutrition and health. Poor growth during the rearing period due to underfeeding and/or disease has been associated with delayed first breeding and first calving [2,3]. Once animals have been bred, their fertility during the breeding period will also affect the age at which they calve. Poor fertility can lead to a large spread in AFC and in practice there may be large differences between the target and actual AFC achieved.

The majority of UK dairy producers aim to start breeding Holstein-Friesian heifers from around 14 - 15 months of age, and thus the target AFC is generally 24 months on UK farms. Most countries, however, report a mean AFC of more than 24 months (e.g. [4-6]) and only 14.6\% of dairy operations surveyed in the US achieved an average AFC of $\leq 25$ months [7].

A number of studies have shown that age and $\mathrm{BW}$ at calving can have a significant effect on both subsequent 
milk production $[4,8]$ and survival in the herd $[9,10]$ although results are not always consistent. Weight at calving is dependent on both age at conception and growth rate and some studies have shown that a higher BW at calving has a positive effect on subsequent milk production $[9,11,12]$. This may, however, be less economical due to higher rearing costs [13]. In contrast, increasing the plane of nutrition during the rearing period, resulting in heavier heifers at first calving, may cause increased fat deposition rather than skeletal growth and impair mammary development, thus reducing subsequent milk yield $[14,15]$. Since most mammary gland development takes place prior to calving, a younger calving age can also potentially reduce the milk production capacity due to sub optimal development of mammary tissue [15]. A reduction in AFC can have a negative effect on first lactation milk yield, associated with a low BW in younger heifers at the start of the first lactation [4]. Nevertheless, reducing the AFC below 26 months produced a positive effect on the difference between milk yield returns and rearing costs, with an AFC of 23 - 24 months being the most profitable [4]. Other studies found no effect of more rapid growth or a younger AFC on milk production in the first lactation [16-18] although adverse effects on lifetime productivity have also been reported [17].

A significant number of heifers $(14 \%-19 \%)$ are culled during their first lactation, with poor fertility a major cause of such high losses of these relatively young animals $[19,20]$. In addition to premature involuntary culling of infertile animals, poor reproductive performance increases the number of services per cow, increases the calving interval and reduces the number of calves sold per year. The effect of AFC on subsequent reproductive performance remains unclear. Calving heifers at 25 26 months had a tendency to lower subsequent calving intervals compared to both younger $(<24$ months) and older age groups at first calving [10]. Similarly, it was reported that lower conception rates were found in the first lactation for both early ( $<700$ days, 23.3 months) and later calving heifers (>751 days, 25 months) in comparison with those calving between $700-750$ days [9]. In contrast, another study found no effect of age on any measure of reproductive performance during the first lactation [21]. Another important consideration is that AFC may influence the incidence of dystocia and calf mortality, as calving difficulties are influenced by the dam's age, relative maturity and pelvic width [22]. However, one study found no effect of maternal age on retained fetal membranes or calf mortality and AFC could be reduced to 22 months without an increased frequency of problems at parturition [23].

Current data on the influence of AFC on the subsequent performance of dairy cows are thus not always in agreement. These differences may in part be caused by variations in genetics and management between different studies and countries. There is also little information available on any influences of AFC on subsequent survival, although this trait is of increasing importance to the dairy industry [24]. Farmers need such information to inform their management decisions on heifer growth rates and breeding strategies. The aim of this study was, therefore, to determine the relationship between AFC and subsequent fertility, milk production and survival up to third calving in two prospective studies undertaken on dairy farms located in southern England which kept Holstein-Friesian cows. The first dataset was collected from a single farm whereas the second was expanded to include 17 farms.

\section{MATERIALS AND METHODS}

\subsection{Animals and Farms}

Recruited farms provided a range of management practices representative of those commonly encountered on UK dairy farms; no aspect of herd management was changed for the duration of the study period. All farms had a target AFC for maiden heifers of approximately 24 months. Heifer calves were recruited at birth and monitored until either removal from the herd, or 5 years of age and/or third calving.

The first dataset (Study 1) comprised 134 consecutively born heifer calves from a single primarily research farm (herd size, 460) born between August and December 2001. The second dataset (Study 2) consisted of 445 heifer calves recruited from the same research farm and 16 commercial dairy farms all keeping Holstein-Friesian cows (median herd size, 228; range, 105 to 540 adult cows) born between August 2003 and October 2004. The recruitment period for each individual farm generally lasted 1 to 4 months during the main calving season, with the aim of obtaining a cohort of approximately 25 consecutively born live heifer calves per farm (mean cohort size 23 , range 12 to 30 ).

\subsection{Growth Parameters and Body Condition Score}

Heifers in Study 1 were weighed at birth, 3, 6, 9 and 15 months of age. Heifers in Study 2 were weighed at approximately 1 month ( $30 \pm 0.9$ days), 6 months (185 \pm 0.8 days), and 15 months ( $447 \pm 3$ days). BW was measured using a portable weigh platform with Tru-Test loadbars connected to an Eziweigh 2 indicator (Ritchey Tagg, Ripon, North Yorkshire, UK). Weigh equipment was calibrated before each sampling session. In Study 2 these data were used to calculate the average daily gain (ADG) in $\mathrm{BW}$ from 1 to 6 and from 6 to 15 months. Body condition score (BCS) for all heifers was measured at approximately 1 to 2 weeks before estimated calving date using 
an 11-point scale from 0 (very thin) to 5 (obese) with increments of 0.5 .

\subsection{Reproductive Performance}

All animals in Study 1 were served exclusively by artificial insemination (AI). Heifers were initially served at the first observed oestrus and then again at any subsequent oestrus from the start of the service period (25 November 2002 until the end of March 2003). Pregnancy was confirmed by transrectal palpation. If an animal was not pregnant at the end of this first insemination period she was turned out to pasture and served again from July 2003 onwards. Following calving, animals were artificially inseminated at observed oestrus after a voluntary wait period of 60 days, and pregnancy was confirmed by transrectal palpation.

Heifers in Study 2 were served either by AI $(n=218)$, an intact bull $(n=110)$, with embryo transfer $(n=12)$, or with a combination $(n=29)$; animals were bred according to the individual farm breeding protocol. A successful insemination, resulting in a conception, was validated by a pregnancy diagnosis (if performed) or by a subsequent calving date and gestation length of $282 \pm 14$ days.

Nulliparous fertility was recorded as age at first breeding (AFB), services per conception (S/C), age at conception, first service conception rate $(\mathrm{CR})$, and AFC (Table 1). After each calving, fertility was recorded as days to first service (DFS), days to conception (DTC), S/C and first service CR (Table 1). For animals failing to conceive, the total number of inseminations given to ach animal, and/or the number of times mated to a bull, before a decision was made to cull them was recorded. The incidence of perinatal mortality (defined as a calf born dead or dying within 24 hours of parturition) was recorded at each calving.

\subsection{Milk Production}

Milk records were collected for each lactation; peak milk yield, 305 day yield, number of days in milk (DIM), and total milk yield. Figures were also calculated over the first 5 years of life including total milk production, total DIM and the proportion of days alive spent in the milking herd (DIM/days alive $\times 100 \%)$. The days alive were capped at the cow's fifth birthday (1825 days) unless the cow had already died or been culled. Milk yield per day of life until third calving was also calculated for animals in Study 2, as total yield over 2 lactations/(cull date or date of $3^{\text {rd }}$ calving - birth date).

\subsection{Statistical Analysis}

Heifers were grouped retrospectively based on their actual AFC; $<700$ days ( $<23$ months), $701-760$ days (23 - 25 months), 761 - 912 days (26 - 30 months) and $>912$ days ( $>30$ months). This grouping strategy was based on the spread in the AFC observed in this study, and because calving at 700 to 750 days is usually considered economically optimum $[9,10]$. All data were initially analysed using Statistical Package for the Social Sciences (SPSS version 18.0; SPSS Inc., Chicago, IL, USA), and were tested for homogeneity of variance before analysis. Categorical data such as perinatal mortality at calving $(0$ $=$ alive calf, $1=$ dead calf) were compared between the four AFC groups using Chi-square analysis. Continuous data were analysed using one-way ANOVA for normally distributed data or non-parametric Kruskal-Wallis tests for data not normally distributed. For Study 2 , traits at $P$ $<0.1$ were further investigated using a linear mixed effects model in SPSS, with posthoc LSD tests, including farm as a random effect and AFC as a fixed effect. Survival data were analysed using Kaplan Meier Survival Analysis, with CoxRegression used for further comparison between AFC groups. Data were considered statistically significant if $P$ values were $\leq 0.05$.

\section{RESULTS}

The data used in these analyses were observational, so the results are associations and cannot be used to imply causality. Of the 134 calves recruited at birth in Study 1, $17(13 \%)$ failed to reach first calving. In Study 2, 51 of the 445 calves recruited (11\%) failed to calve at all due to mortality or culling during the rearing period. In addition, six heifers in Study 2 aborted at $226 \pm 12$ days pregnant and started their first lactation at $698 \pm 20$ days. No further information on these animals is given here.

Table 1. Definition of fertility parameters.

\begin{tabular}{ll}
\hline Fertility trait & Definition \\
\hline Age at first breeding (AFB) & Number of days from birth to the day of first AI, or first contact with a bull, or first embryo transfer \\
Services per conception (S/C) & Number of inseminations before a positive pregnancy diagnosis, or calving event \\
Age at conception & Number of days from birth to the day of conception \\
First service conception rate (CR) & Number of animals pregnant to first AI divided by the total number of animals inseminated \\
Age at first calving (AFC) & Number of days from birth to day of first calving \\
Days to first service (DFS) & Number of days from calving to the day of first insemination \\
Days to conception (DTC) & Number of days from calving to the day of conception \\
\hline
\end{tabular}




\subsection{Age at First Calving}

The mean AFC for all 117 heifers in Study 1 was 764 \pm 8 days (range 662 to 1095 ), and for the 388 heifers in Study 2 it was $796 \pm 6$ days (range 636 to 1529). The mean AFC values were very similar between studies for the 23 month, 23 - 25 month and $>30$ month AFC groups (Table 2). Heifers calving between 26 - 30 months of age were, however, older at calving in Study 2 (827 \pm 3 compared with $787 \pm 4$ days respectively). Figure 1 illustrates the considerable variation found in the AFC both between and within farms in Study 2. For example, Farm 1 achieved an AFC of $719 \pm 14$ days in comparison with Farm 17 where it was $959 \pm 43$ days, about 8 months later on average.

\subsection{Nulliparous Fertility and Growth}

In both studies, heifers in the youngest AFC group ( $<23$ month) had the best fertility, with most heifers conceiving to first service (93\% in Study 1, 84\% in Study 2, Table 2). This good fertility was achieved despite these animals being the youngest at first service with breeding starting at 13 to 14 months of age. The higher AFC values in the other groups were attributable partly to a delayed AFB and partly to a poorer conception rate. The influence of $\mathrm{S} / \mathrm{C}$ was greatest in Study $1(1.1 \pm 0.07$ vs $3.3 \pm 0.3 \mathrm{~S} / \mathrm{C}$ in the $<23$ month and $>30$ month AFC groups respectively). The late calving group were served for the first time at $450 \pm 12$ days, but failed to conceive within the 4 month initial breeding period, so were later put through a second service period. In contrast, AFB was the major influence on AFC in Study 2 (398 \pm 3 vs $609 \pm 31$ days in the $<23$ month and $>30$ month AFC groups respectively), a delay of about 7 months.

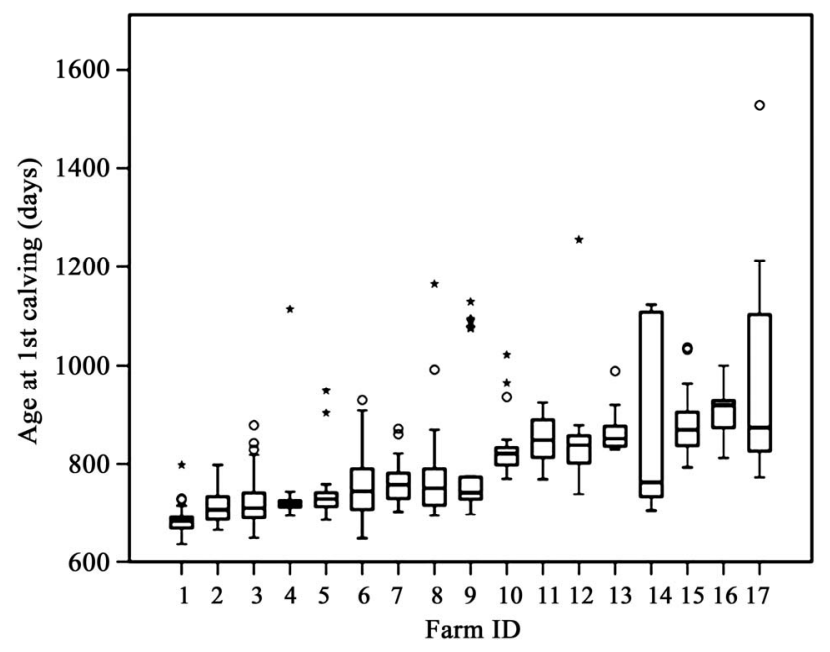

Figure 1. Box and whisker plots showing the AFC for 388 heifers in Study 2 according to their 17 farms of origin. The plots show the median, $25^{\text {th }}$ and $75^{\text {th }}$ percentiles, minimum and maximum observed values, outliers (o) and extreme values $(*)$.

Table 2. Nulliparous heifer fertility in relation to their age at first calving.

\begin{tabular}{|c|c|c|c|c|c|c|}
\hline & \multicolumn{4}{|c|}{ Age at first calving } & \multirow{2}{*}{$\begin{array}{c}\text { ANOVA } \\
P \text {-value }\end{array}$} & \multirow{2}{*}{$\begin{array}{l}\text { Mixed } \\
\text { model }\end{array}$} \\
\hline & $<23 \mathrm{mo}$ & $23-25 \mathrm{mo}$ & $26-30 \mathrm{mo}$ & $>30 \mathrm{mo}$ & & \\
\hline \multicolumn{7}{|l|}{ Study 1} \\
\hline No. heifers & 14 & 61 & 33 & 9 & & \\
\hline $\mathrm{AFB}(\mathrm{d})$ & $407 \pm 4^{c}$ & $444 \pm 2^{b}$ & $459 \pm 5^{\mathrm{a}}$ & $450 \pm 12^{\mathrm{ab}}$ & 0.001 & \\
\hline $\mathrm{S} / \mathrm{C}$ & $1.1 \pm 0.07^{\mathrm{b}}$ & $1.3 \pm 0.07^{\mathrm{b}}$ & $2.4 \pm 0.22^{\mathrm{a}}$ & $3.3 \pm 0.3^{\mathrm{a}}$ & 0.001 & \\
\hline First service CR & $13 / 14(93 \%)$ & 45/61 (74\%) & 9/33 (27\%) & $0 / 9(0 \%)$ & 0.001 & \\
\hline Age at conception (d) & $408 \pm 4^{\mathrm{d}}$ & $451 \pm 2^{\mathrm{c}}$ & $503 \pm 3^{\mathrm{b}}$ & $740 \pm 38^{\mathrm{a}}$ & 0.001 & \\
\hline Actual AFC (d) & $685 \pm 3^{\mathrm{d}}$ & $728 \pm 2^{c}$ & $787 \pm 4^{b}$ & $1041 \pm 12^{\mathrm{a}}$ & 0.001 & \\
\hline \multicolumn{7}{|l|}{ Study 2} \\
\hline No. heifers & 60 & 129 & 155 & 44 & & \\
\hline $\operatorname{AFB}(\mathrm{d})$ & $398 \pm 3^{\mathrm{d}}$ & $436 \pm 2^{\mathrm{c}}$ & $514 \pm 5^{\mathrm{b}}$ & $609 \pm 31^{\mathrm{a}}$ & $<0.001$ & $<0.001$ \\
\hline $\mathrm{S} / \mathrm{C}$ & $1.2 \pm 0.07^{\mathrm{c}}$ & $1.4 \pm 0.07^{\mathrm{b}}$ & $1.7 \pm 0.1^{\mathrm{a}}$ & $1.3 \pm 0.1^{\mathrm{ab}}$ & 0.009 & $<0.001$ \\
\hline First service $\mathrm{CR}^{+}$ & $32 / 38(84 \%)$ & $69 / 100(69 \%)$ & $28 / 55(51 \%)$ & $8 / 12(67 \%)$ & $0.009^{\dagger}$ & \\
\hline Age at conception (d) & $403 \pm 2^{d}$ & $450 \pm 1^{c}$ & $544 \pm 3^{b}$ & $720 \pm 22^{\mathrm{a}}$ & $<0.001$ & $<0.001$ \\
\hline Actual AFC (d) & $680 \pm 2^{d}$ & $729 \pm 1^{c}$ & $827 \pm 3^{\mathrm{b}}$ & $1042 \pm 19^{\mathrm{a}}$ & $<0.001$ & $<0.001$ \\
\hline
\end{tabular}

Values are mean \pm SEM; within rows $\mathrm{a}>\mathrm{b}>\mathrm{c}>\mathrm{d}$ using ANOVA for Study 1 and a mixed model for Study $2 ;{ }^{\dagger}$ Analyzed using Chi square; ${ }^{+}$Includes animals served by AI only. 
BW measurements during rearing for animals in both studies are given in Table 3. In Study 1 there were no differences according to AFC group until 6 months of age, when the youngest AFC group were significantly heavier than their compatriots by about 18 to $20 \mathrm{~kg}$. At 9 and 15 months it was apparent that the late calving group with an $\mathrm{AFC}>30$ months was growing more slowly as they were significantly lighter than the other heifers in the herd at both these time points. In Study 2, heifers in the two oldest AFC groups ( $>26$ month) were similarly lighter at 6 months and exhibited lower ADG of between 0.66 to $0.74 \mathrm{~kg} / \mathrm{d}$ whereas ADG rates for heifers calving at $<26$ months were from 0.78 to $0.85 \mathrm{~kg} / \mathrm{d}$ from $1-15$ months (Table 3). By the time they actually calved, however, the animals in the $>30$ month AFC group in both studies had the highest BCS $(3.9 \pm 0.12$ and $3.8 \pm$ 0.15 , respectively, Table 3 ).

\subsection{Fertility in Lactations 1 and 2}

Data on fertility measures in the first lactation are summarized in Table 4. There was no significant effect of AFC group on DFS or first service CR in either study. In Study 1 , there was a trend $(P=0.075)$ for cows calving at $>30$ months to require more $\mathrm{S} / \mathrm{C}(4.7 \pm 1.7)$, compared with means of 2.2 to 2.6 in the three younger AFC groups. Similarly in Study 2 there was a trend $(P=0.072)$ for a longer interval from calving to conception $(170 \pm 18$ days) for heifers calving at $>30$ months compared with those calving at $<30$ months (means of 117 to 137 days). As expected, AFC was significantly associated with age at second calving; those heifers calving at $<23$ months were on average 361 days (Study 1) and 404 days (Study 2 ) younger at second calving compared to those calving for the first time at $>30$ months $(P<0.001)$.

Table 3. Body weight growth during the heifer rearing period in relation to age at first calving.

\begin{tabular}{|c|c|c|c|c|c|c|}
\hline & \multicolumn{4}{|c|}{ Age at calving } & \multirow{2}{*}{$\begin{array}{c}\text { ANOVA } \\
P \text {-value }\end{array}$} & \multirow{2}{*}{$\begin{array}{l}\text { Mixed } \\
\text { model }\end{array}$} \\
\hline & $<23 \mathrm{mo}$ & $23-25 \mathrm{mo}$ & $26-30 \mathrm{mo}$ & $>30 \mathrm{mo}$ & & \\
\hline \multicolumn{7}{|l|}{ Study 1} \\
\hline No. animals & 10 & 52 & 31 & 9 & & \\
\hline BW birth (kg) & $36 \pm 2.1$ & $35 \pm 0.6$ & $37 \pm 1.1$ & $34 \pm 1.6$ & NS & \\
\hline BW 3 mo (kg) & $96 \pm 4.5$ & $98 \pm 2.1$ & $99 \pm 2.6$ & $93 \pm 5.3$ & NS & \\
\hline BW 6 mo (kg) & $197 \pm 5.3^{\mathrm{a}}$ & $180 \pm 2.8^{b}$ & $177 \pm 2.8^{b}$ & $179 \pm 8.6^{\mathrm{b}}$ & 0.03 & \\
\hline BW 9 mo (kg) & $256 \pm 8.7^{\mathrm{a}}$ & $260 \pm 3.0^{\mathrm{a}}$ & $259 \pm 4.6^{\mathrm{a}}$ & $233 \pm 9.1^{b}$ & 0.032 & \\
\hline BW 15 mo (kg) & $344 \pm 7.5^{\mathrm{bc}}$ & $372 \pm 5.0^{\mathrm{a}}$ & $366 \pm 10.2^{\mathrm{ab}}$ & $325 \pm 8.6^{\mathrm{c}}$ & 0.019 & \\
\hline BCS pre-calving & $2.1 \pm 0.12^{\mathrm{b}}$ & $2.2 \pm 0.07^{\mathrm{b}}$ & $2.3 \pm 0.11^{\mathrm{b}}$ & $3.9 \pm 0.12^{\mathrm{a}}$ & 0.001 & \\
\hline \multicolumn{7}{|l|}{ Study 2} \\
\hline No. animals & 56 & 123 & 145 & 40 & & \\
\hline BW 1 mo (kg) & $65 \pm 2.2$ & $59 \pm 1.8$ & $52 \pm 1.1$ & $54 \pm 1.8$ & $<0.001$ & 0.217 \\
\hline BW 6 mo (kg) & $182 \pm 5$ & $184 \pm 3$ & $160 \pm 3$ & $168 \pm 8$ & $<0.001$ & 0.165 \\
\hline BW 15 mo (kg) & $366 \pm 3.8$ & $365 \pm 2.8$ & $368 \pm 4.4$ & $365 \pm 11.8$ & NS & \\
\hline ADG $1-6 \mathrm{mo}(\mathrm{kg} / \mathrm{d})$ & $0.85 \pm 0.02$ & $0.82 \pm 0.01$ & $0.66 \pm 0.02$ & $0.74 \pm 0.04$ & $<0.001$ & 0.099 \\
\hline BCS pre-calving & $3.1 \pm 0.07^{\mathrm{b}}$ & $3.4 \pm 0.05^{\mathrm{b}}$ & $3.3 \pm 0.04^{\mathrm{b}}$ & $3.8 \pm 0.15^{\mathrm{a}}$ & $<0.001$ & 0.034 \\
\hline
\end{tabular}

Values are mean $\pm \mathrm{SEM}$; within rows $\mathrm{a}>\mathrm{b}$ using ANOVA for Study 1 and a mixed model for Study 2; NS = not significant.

Table 4. Reproductive performance of cows during their first lactation in relation to age at first calving.

\begin{tabular}{|c|c|c|c|c|c|c|}
\hline & \multicolumn{4}{|c|}{ Age at calving } & \multirow{2}{*}{$\begin{array}{c}\text { ANOVA } \\
P \text {-value }\end{array}$} & \multirow{2}{*}{$\begin{array}{l}\text { Mixed } \\
\text { model }\end{array}$} \\
\hline & $<23 \mathrm{mo}$ & $23-25 \mathrm{mo}$ & $26-30 \mathrm{mo}$ & $>30 \mathrm{mo}$ & & \\
\hline \multicolumn{7}{|l|}{ Study 1} \\
\hline No. dead calves & $1 / 14(7 \%)$ & $10 / 61(16 \%)$ & $4 / 33(12 \%)$ & $5 / 9(55 \%)$ & $0.011^{\dagger}$ & \\
\hline DFS & $90 \pm 8$ & $86 \pm 3$ & $76 \pm 5$ & $97 \pm 18$ & NS & \\
\hline $1^{\text {st }}$ service $\mathrm{CR}$ & $5 / 14(36 \%)$ & $27 / 58(46 \%)$ & $10 / 33(30 \%)$ & $1 / 4(25 \%)$ & $\mathrm{NS}^{\dagger}$ & \\
\hline $\mathrm{S} / \mathrm{C}$ & $2.6 \pm 0.52$ & $2.2 \pm 0.24$ & $2.6 \pm 0.32$ & $4.7 \pm 1.65$ & 0.075 & \\
\hline DTC & $180 \pm 33$ & $140 \pm 13$ & $135 \pm 16$ & $238 \pm 99$ & NS & \\
\hline Age at $2^{\text {nd }}$ calving $(d)$ & $1147 \pm 34^{\mathrm{b}}$ & $1142 \pm 11^{\mathrm{b}}$ & $1233 \pm 22^{\mathrm{a}}$ & $1447 / 1568^{+}$ & 0.001 & \\
\hline \multicolumn{7}{|l|}{ Study 2} \\
\hline Starting no. cows & 60 & 129 & 155 & 44 & & \\
\hline No. dead calves ${ }^{\#}$ & $14 / 60(23 \%)$ & $20 / 123(16 \%)$ & $28 / 148(19 \%)$ & $7 / 40(18 \%)$ & $\mathrm{NS}^{\dagger}$ & \\
\hline DFS & $86 \pm 3$ & $78 \pm 2$ & $82 \pm 3$ & $82 \pm 6$ & NS & NS \\
\hline $1^{\text {st }}$ service $\mathrm{CR}$ & $27 / 58(47 \%)$ & $52 / 124(42 \%)$ & $55 / 140(39 \%)$ & $13 / 41(32 \%)$ & $\mathrm{NS}^{\dagger}$ & \\
\hline $\mathrm{S} / \mathrm{C}$ & $2.4 \pm 0.3$ & $2.2 \pm 0.2$ & $2.5 \pm 0.2$ & $3.0 \pm 0.4$ & NS & NS \\
\hline Age at $2^{\text {nd }}$ calving $(d)$ & $1088 \pm 12^{\mathrm{d}}$ & $1131 \pm 10^{\mathrm{c}}$ & $1248 \pm 11^{\mathrm{b}}$ & $1492 \pm 24^{\mathrm{a}}$ & $<0.001$ & $<0.001$ \\
\hline
\end{tabular}

Values are mean \pm SEM; within rows $\mathrm{a}>\mathrm{b}>\mathrm{c}>\mathrm{d}$ using ANOVA for Study 1 and a mixed model for Study $2 ;$ NS $=$ not significant; ${ }^{\prime}$ Not all recorded; ${ }^{\dagger}$ Analyzed using Chi square; ${ }^{+} \mathrm{n}=2$. 
In Study 1 none of the fertility parameters measured in lactation 2 differed according to AFC group (Table 5). This lack of significance was in part due to the fact that only 2 cows in the $>30$ month AFC group calved for a second time and none of these reached third calving. In Study 2, animals calving at $>30$ months had a longer DFS (92 \pm 7 days) in their second lactation compared to the other AFC groups which had mean DFS values of 81, 72 and 70 days respectively $(P<0.001)$. Other fertility parameters did not differ.

The overall relationship between the age at first calving and at subsequent calvings for all the animals in Study 2 is summarized in Figure 2. Heifers calving initially at $<23$ months calved for a third time at 1512 days. This was similar to the age at second calving of 1492 days for the $>30$ month AFC group. The $<23$ month group were on average 432 days younger at third calving compared to those calving for the first time at $>30$ months ( $<<0.001$, Table 5) and therefore fitted a whole extra lactation into the same time period from birth.

\subsection{Perinatal Mortality}

The overall levels of perinatal mortality were similar between the two studies, $17 \%$ and $19 \%$, for Study 1 and 2 respectively at first calving and $8 \%$ and $6 \%$ at second calving. Older calving cows in Study 1 produced more dead calves at first calving $(7 \%, 16 \%, 12 \%$ and $55 \%$ per AFC group respectively, $P=0.011$, Table 4). At second calving one of the two animals in the $>30$ month AFC group produced dead twins, whereas in all the other AFC groups the dead calf rate was consistent at 7\% (Table 5). In Study 2, in contrast, there was no significant difference in perinatal mortality between the AFC groups at first calving but at second calving there was a trend for animals with an AFC $>30$ months to produce more dead calves $(0 \%, 9 \%, 4 \%$ and $13 \%$ per AFC group respectively, $P=0.075$, Table 5).

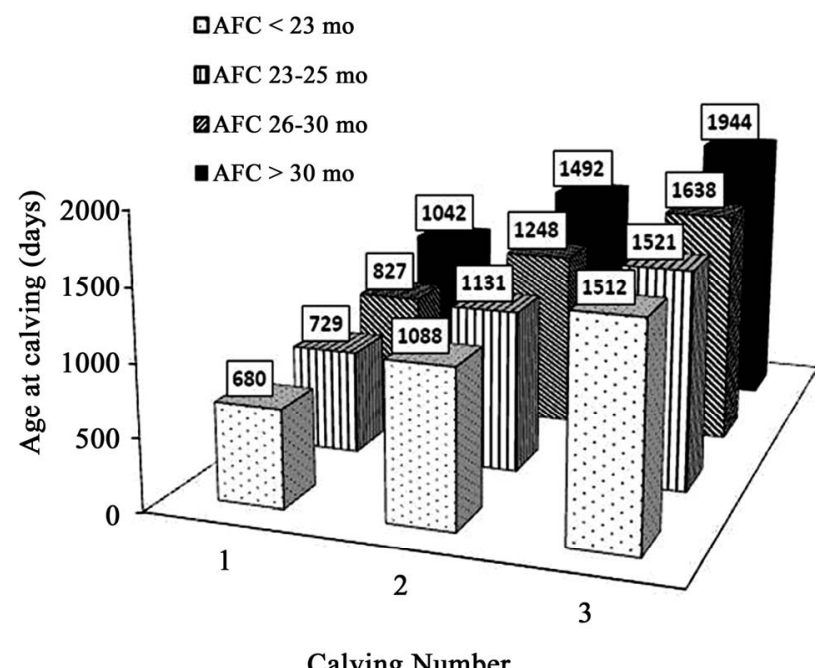

Figure 2. Summary diagram illustrating the effect of age at first calving in Study 2 on the ages of animals at their second and third calving. The mean age for the surviving animals at each calving is given in the box above the relevant bar. The starting number of animals in each AFC group was as follows: $<23$ months, $\mathrm{n}=60 ; 23-25$ months, $\mathrm{n}=129 ; 26-30$ months, $\mathrm{n}=155$ and $>30$ months, $n=44$. See Tables 4 and 5 for further details.

Table 5. Reproductive performance of cows during their second lactation in relation to age at first calving.

\begin{tabular}{|c|c|c|c|c|c|c|}
\hline & \multicolumn{4}{|c|}{ Age at calving } & \multirow{2}{*}{$\begin{array}{l}\text { ANOVA } \\
P \text {-value }\end{array}$} & \multirow{2}{*}{$\begin{array}{l}\text { Mixed } \\
\text { model }\end{array}$} \\
\hline & $<23 \mathrm{mo}$ & $23-25 \mathrm{mo}$ & $26-30 \mathrm{mo}$ & $>30 \mathrm{mo}$ & & \\
\hline \multicolumn{7}{|l|}{ Study 1} \\
\hline No. cows & $14 / 14(100 \%)$ & $53 / 61(87 \%)$ & $28 / 33(85 \%)$ & $2 / 9(22 \%)$ & & \\
\hline No. dead calves & $1 / 14(7 \%)$ & $4 / 53(7 \%)$ & $2 / 28(7 \%)$ & $1 / 2(50 \%)$ & NS & \\
\hline DFS & $95 \pm 12$ & $87 \pm 5$ & $92 \pm 6$ & $94 \pm 10$ & NS & \\
\hline $1^{\text {st }}$ service $\mathrm{CR}$ & $7 / 14(50 \%)$ & $14 / 47(30 \%)$ & $6 / 20(30 \%)$ & $1 / 2(50 \%)$ & NS & \\
\hline $\mathrm{S} / \mathrm{C}$ & $1.5 \pm 0.18$ & $2.5 \pm 0.23$ & $2.5 \pm 0.35$ & $1(n=1)$ & NS & \\
\hline DTC & $97 \pm 12$ & $146 \pm 14$ & $153 \pm 21$ & $84(\mathrm{n}=1)$ & NS & \\
\hline Age at $3^{\text {rd }}$ calving (d) & $1551 \pm 64$ & $1539 \pm 26$ & $1592 \pm 46$ & None & NS & \\
\hline No. cows at $3^{\text {rd }}$ calving & $9 / 14(64 \%)$ & 29/61 (48\%) & $9 / 33(27 \%)$ & $0 / 9(0 \%)$ & $0.004^{\dagger}$ & \\
\hline \multicolumn{7}{|l|}{ Study 2} \\
\hline No. cows & $51 / 60(85 \%)$ & $109 / 129(84 \%)$ & $122 / 155(79 \%)$ & $34 / 44(77 \%)$ & & \\
\hline No. dead calves ${ }^{\#}$ & $0 / 48(0 \%)$ & $8 / 94(9 \%)$ & $4 / 99(4 \%)$ & $3 / 24(13 \%)$ & $0.075^{\dagger}$ & \\
\hline DFS & $81 \pm 4$ & $72 \pm 3^{b}$ & $70 \pm 2^{b}$ & $92 \pm 7^{\mathrm{a}}$ & 0.001 & 0.001 \\
\hline $1^{\text {st }}$ service $\mathrm{CR}$ & $13 / 46(28 \%)$ & 48/102 (47\%) & $38 / 108(35 \%)$ & $10 / 30(33 \%)$ & NS & \\
\hline $\mathrm{S} / \mathrm{C}$ & $2.7 \pm 0.3$ & $2.1 \pm 0.2$ & $2.6 \pm 0.3$ & $2.2 \pm 0.3$ & NS & NS \\
\hline DTC & $127 \pm 11$ & $111 \pm 7$ & $133 \pm 11$ & $144 \pm 20$ & NS & NS \\
\hline Age at $3^{\text {rd }}$ calving $(\mathrm{d})$ & $1512 \pm 21^{\mathrm{c}}$ & $1521 \pm 14^{c}$ & $1638 \pm 15^{b}$ & $1944 \pm 38^{\mathrm{a}}$ & $<0.001$ & $<0.001$ \\
\hline No. cows at $3^{\text {rd }}$ calving & $37 / 60(62 \%)$ & $90 / 129(70 \%)$ & $92 / 155(59 \%)$ & $22 / 44(50 \%)$ & $0.091^{\dagger}$ & \\
\hline
\end{tabular}

Values are mean \pm SEM; within rows $\mathrm{a}>\mathrm{b}>\mathrm{c}$ using ANOVA for Study 1 and a mixed model for Study 2 ; $\mathrm{NS}=$ not significant; ${ }^{*}$ Not all recorded; ${ }^{\dagger}$ Analyzed using Chi square. 


\subsection{Survival}

Overall 59 cows of the 134 heifers recruited in Study 1 were still alive in the herd on their fifth birthday, representing $44 \%$ of those born, and $50 \%$ of those which reached first calving. In Study 2, 228 cows of the 439 recruited (excluding the 6 that aborted their first pregnancy) were still alive in the herd on their fifth birthday, representing $52 \%$ of those born, and $59 \%$ of those which reached first calving. Regardless of age, a total of 241 cows of the 439 heifers recruited in Study 2 calved for a third time $(55 \%)$.

In Study 1, the number reaching third calving reduced from $64 \%$ of the $<23$ month AFC group to $0 \%$ of the $>30$

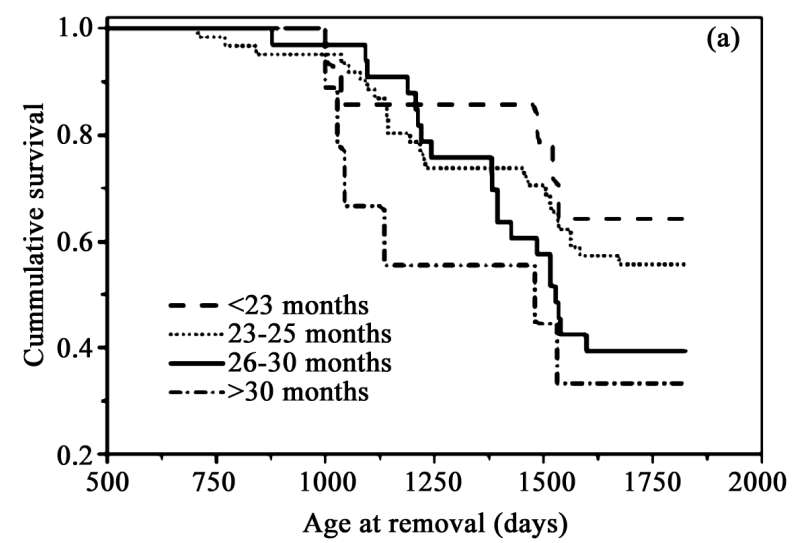

month AFC group (Table 5). Cox regression analysis showed that the youngest AFC group survived the longest in the herd (Figure 3(a), $P<0.05$ ); 86\% were still alive after 5 years (Table 6). Kaplan-Meier survival analysis showed that, as AFC increased, cows were at a significantly increased risk of leaving the herd prematurely $(P$ $<0.01$, hazard ratio $=1.7)$. Primary reasons given for culling at any time after first calving in order of importance were as follows: infertility $(\mathrm{n}=10)$, mastitis $(\mathrm{n}=9)$, calving related problem $(\mathrm{n}=8)$, low yield $(\mathrm{n}=7)$, accident $(\mathrm{n}=4)$, lame $(\mathrm{n}=3)$, metabolic problem $(\mathrm{n}=3)$, aborted second pregnancy $(n=2)$ and infection $(n=2)$. Numbers of cows in each category were too low to relate these to the AFC groups.

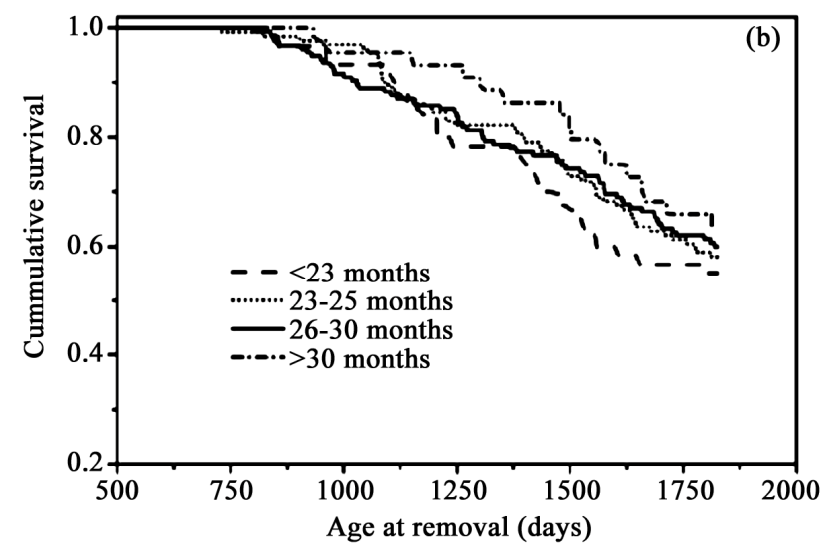

Figure 3. Survival curves up to 5 years of life, according to AFC group in (a) Study 1 and (b) Study 2. The numbers of starting animals per AFC group were: Study $1,<23$ months, $\mathrm{n}=14 ; 23-25$ months, $\mathrm{n}=61 ; 26-30$ months, $\mathrm{n}=33$ and $>30$ months, $\mathrm{n}=9$ and Study $2,<23$ months, $\mathrm{n}=60 ; 23-25$ months, $\mathrm{n}=129 ; 26-30$ months, $\mathrm{n}=155$ and $>30$ months, $\mathrm{n}=44$. In Study 1 animals calving at $>30$ months survived less time in comparison with the other AFC groups $(P<0.05)$. In Study 2 there was no significant difference in survival time between the AFC groups.

Table 6. Milk production in the first three lactations in relation to age at first calving in Study 1.

\begin{tabular}{|c|c|c|c|c|c|}
\hline & \multicolumn{4}{|c|}{ Age at first calving } & \multirow{2}{*}{$P$} \\
\hline & $<23$ mo & $23-25 \mathrm{mo}$ & $26-30 \mathrm{mo}$ & $>30 \mathrm{mo}$ & \\
\hline \multicolumn{6}{|l|}{ First Lactation } \\
\hline No. cows & 14 & 61 & 33 & 9 & \\
\hline No. short lactations $<55 \mathrm{~d}$ & 0 & 3 & 0 & 4 & \\
\hline Peak milk yield (kg/d) & $30 \pm 1.1^{\mathrm{ab}}$ & $33 \pm 1.0^{\mathrm{ab}}$ & $31 \pm 0.8^{\mathrm{a}}$ & $26 \pm 3.8^{\mathrm{b}}$ & 0.025 \\
\hline Total $\mathrm{DIM}^{+}$ & $359 \pm 17(\mathrm{n}=14)$ & $341 \pm 8(\mathrm{n}=58)$ & $342 \pm 13(n=33)$ & $392 \pm 397(\mathrm{n}=5)$ & NS \\
\hline Total milk yield $(\mathrm{kg})^{+}$ & $8898 \pm 393$ & $9030 \pm 296$ & $8677 \pm 328$ & $10,348 \pm 747$ & NS \\
\hline \multicolumn{6}{|l|}{ Second lactation } \\
\hline No. cows & 14 & 50 & 27 & 2 & \\
\hline Peak milk yield $(\mathrm{kg} / \mathrm{d})$ & $39 \pm 1.0^{\mathrm{a}}$ & $38 \pm 1.0^{\mathrm{a}}$ & $33 \pm 2.0^{\mathrm{b}}$ & $39 / 44(n=2)$ & 0.007 \\
\hline Total DIM & $315 \pm 12^{\mathrm{a}}$ & $313 \pm 15^{\mathrm{a}}$ & $245 \pm 29^{b}$ & $277(\mathrm{n}=1)$ & 0.042 \\
\hline Total milk yield $(\mathrm{kg})$ & $9865 \pm 429^{\mathrm{a}}$ & $9018 \pm 475^{\mathrm{a}}$ & $6819 \pm 870^{\mathrm{b}}$ & $8005(\mathrm{n}=1)$ & 0.013 \\
\hline \multicolumn{6}{|l|}{5 years of life } \\
\hline No. cows still alive $(\%)$ & $12 / 14(86 \%)$ & $38 / 61(62 \%)$ & $16 / 33(41 \%)$ & $3 / 9(33 \%)$ & 0.039 \\
\hline Total DIM for 5 years & $861 \pm 36^{\mathrm{a}}$ & $714 \pm 34^{\mathrm{ab}}$ & $608 \pm 40^{\mathrm{a}}$ & $295 \pm 94^{\mathrm{c}}$ & 0.001 \\
\hline Total 5 year milk yield $(\mathrm{kg})$ & $25031 \pm 1491^{\mathrm{a}}$ & $20395 \pm 1127^{\mathrm{ab}}$ & $16671 \pm 1335^{\mathrm{b}}$ & $8029 \pm 2780^{c}$ & 0.001 \\
\hline$\%$ life in first 5 years spent in milk & $54 \pm 3.6 \%{ }^{\mathrm{a}}$ & $44 \pm 1.9 \%^{\mathrm{b}}$ & $38 \pm 1.6 \%{ }^{\mathrm{b}}$ & $18 \pm 0.5 \%{ }^{\mathrm{c}}$ & 0.001 \\
\hline
\end{tabular}

Values are mean $\pm \mathrm{SEM}$; within rows $\mathrm{a}>\mathrm{b}>\mathrm{c} ; \mathrm{NS}=$ not significant; ${ }^{+}$Excluding short lactations $<55 \mathrm{~d}$; ${ }^{\#} \mathrm{DIM} /$ days alive $\times 100 \%$. 
Of the 388 heifers calving for the first time in Study 2, 24 were not served during lactation 1 (culled after $219 \pm$ 63 DIM, range 3 to 918 days), and 26 failed to conceive $(7 \%, \mathrm{n}=26 / 364)$. Animals failing to conceive received a mean of $3.1 \pm 0.5$ inseminations (range 1 to 11 ). For animals which conceived $(\mathrm{n}=338)$, the mean number of $\mathrm{S} / \mathrm{C}$ was $2.5 \pm 0.1$ (range 1 to 18 ) but 22 of these failed to calve again. A total of 316 animals therefore calved for a second time. Of these, 30 animals were not subsequently served and 24 failed to conceive $(8 \%, \mathrm{n}=24 / 286)$ despite receiving a mean of $4.6 \pm 0.7$ inseminations (range 1 to 13$)$. For animals which did conceive $(n=262)$, the mean number of $\mathrm{S} / \mathrm{C}$ was $2.4 \pm 0.1$ (range 1 to 17 ) but 21 failed to calve again. A total of 241 animals therefore calved for a third time. As in Study 1, as AFC increased beyond 25 months proportionately fewer animals in Study 2 achieved a third calving (Table 5); $70 \%$ of heifers calving at 23 - 25 months calved for a third time, compared to only $50 \%$ of those calving for the first time at $>30$ months. In contrast to Study 1, a smaller proportion of heifers in the $<23$ month AFC group reached third calving $(62 \%)$ compared to the number of heifers calving at 23 - 25 months $(70 \%)$. Despite more of the $23-25$ month AFC group successfully reaching a third calving, there was no significant difference between the AFC groups in the survival analysis up to 5 years (Figure 3(b)) or in the number of cows still alive at 5 years (range $55 \%$ to $64 \%$, Table 7). Primary reasons given for culling at any time after first calving in order of importance were as follows: infertility $(\mathrm{n}=48)$, infection or sick $(\mathrm{n}=18)$, mastitis or high somatic cell count $(n=17)$, abortion or embryo loss $(n=13)$, skeletal injury $(n=13)$, other $(n=$ $10)$, calving related problems $(n=7)$, accident $(n=6)$, mammary or teat conformation $(n=6)$, low yield $(n=2)$ and lame-ness $(n=2)$. A total of 59 animals either died or were culled or sold with no reason recorded.

\subsection{Productivity}

There were relatively few differences in milk production in the first 2 lactations according to AFC category. In Study 1 older calving cows performed worst, with the lowest peak milk yield (PMY) in the $>30$ month AFC group in the first lactation and only 1 cow completing a second lactation (Table 6). The 26 - 30 month AFC group produced less total milk in the second lactation than the younger calving cows. In Study 2 the ANOVA suggested that the $<23$ month AFC group had a slightly lower PMY in the first and second lactations and the lowest $305 \mathrm{~d}$ yield in the second lactation, with the 26 30 month AFC group performing best in both lactations 1 and 2. The significance of these differences between groups disappeared, however, when mixed model analysis accounting for herd was used (Table 7).

Table 7. Milk production in the first three lactations in relation to age at first calving in Study 2.

\begin{tabular}{|c|c|c|c|c|c|c|}
\hline & \multicolumn{4}{|c|}{ Age at first calving } & \multirow{2}{*}{$\begin{array}{c}\text { ANOVA } \\
P \text {-value }\end{array}$} & \multirow{2}{*}{$\begin{array}{l}\text { Mixed } \\
\text { model }\end{array}$} \\
\hline & $<23 \mathrm{mo}$ & $23-25 \mathrm{mo}$ & $26-30 \mathrm{mo}$ & $>30 \mathrm{mo}$ & & \\
\hline \multicolumn{7}{|l|}{ First lactation } \\
\hline No. cows & $60 / 59$ & $129 / 109$ & $155 / 147$ & $44 / 38$ & & \\
\hline No. short lactations $<55 \mathrm{~d}$ & 0 & 2 & 7 & 2 & & \\
\hline Peak milk yield (kg/d) & $32 \pm 1$ & $33 \pm 1$ & $35 \pm 1$ & $35 \pm 1$ & 0.04 & NS \\
\hline 305 d yield $(\mathrm{kg})$ & $8494 \pm 206$ & $8811 \pm 167$ & $9103 \pm 166$ & $8914 \pm 335$ & NS & NS \\
\hline Total DIM ${ }^{+}$ & $355 \pm 14$ & $349 \pm 11$ & $357 \pm 12$ & $377 \pm 17$ & NS & NS \\
\hline Total milk yield $(\mathrm{kg})^{+}$ & $9384 \pm 335$ & $9420 \pm 339$ & $9985 \pm 346$ & $10,136 \pm 585$ & NS & NS \\
\hline \multicolumn{7}{|l|}{ Second lactation } \\
\hline No. cows & 51 & 109 & 122 & 34 & & \\
\hline No. short lactations $<55 \mathrm{~d}$ & 2 & 2 & 2 & 0 & & \\
\hline Peak milk yield (kg/d) & $40 \pm 1$ & $41 \pm 1$ & $44 \pm 1$ & $43 \pm 2$ & 0.005 & NS \\
\hline 305 d yield $(\mathrm{kg})$ & $9340 \pm 210$ & $9908 \pm 190$ & $10,546 \pm 183$ & $9633 \pm 537$ & 0.001 & NS \\
\hline Total DIM ${ }^{+}$ & $320 \pm 12$ & $325 \pm 9$ & $356 \pm 11$ & $340 \pm 24$ & NS & NS \\
\hline Total milk yield $(\mathrm{kg})^{+}$ & $9624 \pm 408$ & $10,055 \pm 295$ & $11,194 \pm 325$ & $9748 \pm 678$ & 0.008 & NS \\
\hline \multicolumn{7}{|l|}{5 years of life } \\
\hline No. cows still alive (\%) & $33 / 60(55 \%)$ & $74 / 129(57 \%)$ & $93 / 155(60 \%)$ & $28 / 44(64 \%)$ & NS & \\
\hline Total DIM for 5 years & $731 \pm 42^{\mathrm{a}}$ & $763 \pm 27^{\mathrm{a}}$ & $692 \pm 25^{\mathrm{a}}$ & $587 \pm 38^{\mathrm{b}}$ & 0.012 & 0.026 \\
\hline Total 5 year milk yield (kg) & $21,072 \pm 1400^{\mathrm{a}}$ & $22,477 \pm 912^{\mathrm{a}}$ & $20,605 \pm 863^{\mathrm{a}}$ & $15,777 \pm 1237^{\mathrm{b}}$ & 0.005 & 0.021 \\
\hline$\%$ life in first 5 years spent in milk & $46 \pm 2 \%^{a}$ & $45 \pm 1 \%{ }^{\mathrm{a}}$ & $40 \pm 1 \%{ }^{\mathrm{b}}$ & $34 \pm 2 \%^{c}$ & $<0.001$ & $<0.001$ \\
\hline \multicolumn{7}{|l|}{ Up to $3^{\text {rd }}$ calving } \\
\hline Milk per day of life, $\mathrm{kg}^{\dagger}$ & $12.0 \pm 0.4^{\mathrm{a}}$ & $11.8 \pm 0.3^{\mathrm{a}}$ & $10.9 \pm 0.4^{\mathrm{a}}$ & $9.0 \pm 0.6^{\mathrm{b}}$ & $<0.001$ & 0.008 \\
\hline
\end{tabular}

Values are mean \pm SEM; within rows a $>$ b $>$ c using a mixed model analysis; NS $=$ not significant; ${ }^{+}$Excluding short lactations $<55 \mathrm{~d} ;{ }^{\#}$ DIM/days alive $\times 100 \%$; ${ }^{\dagger}$ Calculated as total yield over 2 lactations/(cull date or calving 3 date- - birth date). 
When milk production was instead considered according to production over 5 years of life, then the benefit of a younger calving age became clearly apparent (Tables 6 and 7). In Study 1 cows with an AFC of $<23$ months spent $54 \%$ of their life to date in milk production with a total yield of 25,031 $\pm 1491 \mathrm{~kg}$. In Study 2 all cows calving at $<26$ months had similar productivity, spending $45 \%-46 \%$ of their lives in milk production with total yields of $21,072 \pm 1400 \mathrm{~kg}$ and $22,477 \pm 912$ $\mathrm{kg}$ in the $<23$ months and $23-25$ months AFC groups respectively. In contrast, animals calving at $>30$ months spent only 18\% (Study 1, Table 6) or 34\% (Study 2, Table 7) of their lives in milk production, with total yields over 5 years of $8029 \pm 2780 \mathrm{~kg}$ in Study 1 and 15,777 \pm $1237 \mathrm{~kg}$ in Study 2. Milk produced per day of life therefore decreased progressively from $12.0 \pm 0.4 \mathrm{~kg}$ in the $<23$ month AFC group to $9.0 \pm 0.6 \mathrm{~kg}$ in the $>30$ month AFC group (Table 7).

\section{DISCUSSION}

The results of this study show that the animals which calved for the first time at 23 - 25 months outperformed their later calving compatriots in terms of fertility, milk production and survival over their first 5 years of life.

The mean AFC was 25.5 months in Study 1 and 26.5 months in Study 2 despite a target AFC of 24 months on all farms, confirming previous reports of delays in AFC in other countries. For example, AFC averaged 25.8 months in Ireland [10], 28.1 months in Italy [4], 28.4 months in Sweden [25] and 29.3 months in China [26]. The considerable variation in calving age observed both within and between farms may be attributed to differences in age at first breeding as a result of farm management and/or poor growth rate, or it may be primarily related to heifer fertility. Heifers with poor initial conception rates or with late embryonic/early fetal loss will clearly calve later than those which conceive first time. Around $1.3 \%$ to $4.8 \%$ of heifers also abort their first pregnancy $[2,27]$. This resulted in either immediate culling, a late AFC if they needed rebreeding or a young AFC if their pregnancy was sufficiently advanced to initiate a lactation. Those which did enter the milking herd following an abortion were 2.73 times more likely to be culled in their first lactation [27]. In our two studies the difference in performance in relation to the AFC was later compounded by differential fertility and survival of the lactating cows: thus in Study 1, 57\% of the youngest calving AFC group achieved three lactations after 5 years and $64 \%$ remained alive, whereas no animal calving later than 30 months calved for a third time. In Study 2, 67\% of the 23 - 25 months AFC group remained alive for a third lactation within 5 years, compared to only $16 \%$ of those calving for the first time at $>30$ months. Similarly, animals needing more $\mathrm{S} / \mathrm{C}$ as heifers were less likely to survive in the herd until their second lactation [27].

It is widely accepted that Holstein-Friesian cows have suffered reducing fertility over the past 40 years as genetic selection for milk yield has increased [24]. Less focus has been placed on the fertility of nulliparous heifers. In this study, the overall first service CR was $57 \%$ and $67 \%$ for heifers in Study 1 and 2, respectively. This was considerably higher than the $40 \%$ achieved across all animals in the first lactation but still leaves room for improvement. Others have reported figures for maiden heifers in the range $47 \%$ to $71 \%[9,28,29]$. In agreement with our data, fertility deteriorated as heifers aged, with first service conception rates of $56 \%$ for heifers first bred at $13-16$ months falling to $42 \%$ at $26-27$ months [29].

Growth rate is a major influence on heifer fertility. Heifers in Study 2 calving at $>30$ months were deemed too small to breed at 15 months, resulting from poor growth during the rearing period, and were not bred until on average 20 months of age. Growth rates vary considerably according to plane of nutrition. We previously reported differences in ADG between 1 - 6 months of 0.5 to $1.0 \mathrm{~kg} / \mathrm{d}$ between farms [30]. Growth rates are, however, as variable between different heifers on the same farm: for example, a range of $0.45-1.15 \mathrm{~kg} / \mathrm{d}$ was found on one farm [30] and similar results were found in another study [31]. In Study 1 all heifers were managed in the same way, so the lower growth rate in the $>30$ month AFC group did not relate to plane of nutrition provided. Such differences may potentially be caused by variations in intake between animals in a group associated with dominance hierarchy. More commonly, however, low growth is associated with the common calfhood diseases of diarrhoea, respiratory disease and septicaemia. In particular, the duration of pneumonia before 6 months influenced weight gains [31].

Our results have confirmed previous reports that AFC affects fertility in the first lactation. Analysis of growth trajectories in dairy cows until the end of the third lactation show that animals continue to grow during this entire period, although growth rate slows once the animal reaches approximately 450 days of age [32]. Younger calving cows must therefore continue to grow to a greater extent after calving and this nutrient demand for growth will be at the expense of fertility. On the other hand, those animals calving in the oldest group had the highest pre-calving BCS of 3.8 - 3.9, indicating that these animals had become too fat. It is thought that heifers calving with higher body condition subsequently mobilise more tissue, which also has deleterious consequences on fertility [33]. In accord with this, animals calving at 23 - 25 months in both studies tended to have the best fertility in their first lactation. This is similar to previous reports for spring calving Irish cows; heifers 
calving at $25-26$ months had a tendency for a lower subsequent calving interval compared to both younger $(<24$ months) and older age groups at first calving [10]. Similarly, lower CRs in the first lactation were found for both early $(<23.3$ months) and later calving heifers $(>25$ months) in comparison with those calving between 700 750 days [9].

Despite the variations in fertility, there were no significant differences in first lactation milk production between any of the AFC groups, other than peak milk yield in Study 1 which was lowest in the $>30$ month AFC group. This is an important observation because dairy producers often associate a younger AFC with lower first lactation milk yields. In the second lactation, the 26 - 30 months AFC group in Study 1 produced the lowest total yields and the youngest AFC group had the highest milk yields, while too few of the $>30$ months AFC group survived to make a valid comparison. In Study 2, in contrast, the 26 - 30 months AFC group produced numerically the highest total yields in both lactations but this difference was not significant when herd was considered. This suggests that genetic and/or management differences between herds were having a greater influence on yield than AFC. A number of previous studies have similarly found no adverse effects of lower AFCs on first lactation milk production [16-18]. On the other hand, others have reported that milk yields were higher in older animals at first calving [4,9]. A comparison of animals fed to calve at similar ages (24 - 25 months) but differing weights $(540$ or $620 \mathrm{~kg}$ ) concluded that animals calving at lower weights produced less milk in the first but not the second and third lactations and were overall more economic to keep [13]. This is in accord with an American study which reported that reducing AFC by 1 month lowered the cost of the replacement programme by $4.3 \%$ [1]. Together these data support the idea that a younger AFC does not have a detrimental effect on lifetime milk production capacity.

Previous studies have differed in their findings of calving difficulty experienced in relation to AFC. Fetopelvic disproportion is the main cause of dystocia in cows calving for the first time [22]. Some studies have reported no differences in the incidence of stillbirth and retained fetal membranes with age in animals with an AFC of $>22$ months $[23,34]$. We found that younger calving animals $(<23$ months) in Study 2 suffered the highest level of perinatal mortality (23\%) at first calving. This finding is in agreement with previous reports that the incidence of stillborn calves was lower for high (>750 days, 13.5\%) compared with low ( $<700$ days, $16.1 \%$ ) and medium (701 to 750 days, 19.8\%) AFC heifers [9]. Likewise, the probability of perinatal mortality increased at an increasing rate as heifers calved at a younger age relative to the median AFC of 759 days [22].
We did, however, also find that the animals calving at $<23$ months suffered from the lowest proportion of dead calves at first (7\%, Study 1) and second ( $0 \%$, Study 2$)$ calving. The late calving group, which had become too fat, suffered $55 \%$ calf mortality at first calving (Study 1), and $13 \%$ mortality at second calving (Study 2). There are several inter-related causes of calving difficulty and perinatal mortality, including the dam age and size, and calf size. Calving heifers as early as 22 months did not, however, increase difficulty; size of the dam not age was more important [34]. This, together with our findings is of particular interest as it is widely reported that primiparous cows have a higher incidence of perinatal mortality than older animals [35-37]. These results indicate that it is possible to achieve adequate skeletal maturity to calve successfully by 23 months in Holstein-Friesian heifers providing early growth is adequate.

One of the key findings of this study was that the younger calving groups $(<26$ months) quite clearly produced the most milk per cow over 5 years of life associated with both more lactations per unit of time and a higher survival rate. Heifers do not become profitable until half way through their second lactation and we found that survival to lactation 2 was better for younger calving heifers $(100 \%$ and $85 \%$ for Study 1 and 2, respectively). A number of previous reports also indicate that cows calving at a relatively young age have longer survival. For example, highest survival was achieved with an AFC of 25 - 26 months [10]. Calving at 23 months compared to 26 months increased productive life by 107 days and overall milk production by $1475 \mathrm{~kg}$ [38]. A large retrospective study of the records from Iranian Holsteins found that both milk yield and productive life increased with reducing AFC as long as this was not below 21 months [39]. In Sweden, the risk of culling increased with AFC [25]; cows calving at 28 to 31 months were at a higher risk than those calving at $\leq 25$ months [40]. Slightly higher survival rates to second calving were found for heifers calving at 25 to 27 months [21] while another study reported a lower AFC in cows completing their first lactation in comparison with those which did not [27]. It has also been found that calving heifers at $23-24$ months is more profitable, based on the difference between milk yield returns and rearing costs [4]. Together, these findings provide strong evidence that it is more economical to rear heifers to calve at younger ages, and that these heifers will have better survival rates to second and third calving. Heifers failing to survive at least one lactation are clearly uneconomic to rear, and herd profitability would increase if more animals survived beyond their first lactation.

In conclusion, optimum performance in UK HolsteinFriesian cows over 5 years of life was achieved with an AFC of 23 - 25 months, as these animals performed well 
in terms of both production and fertility and so survived longer in the herd. They were also more likely to achieve 3 lactations; this is crucial for profitability, which increases as lactation number increases. Improving reproductive efficiency of heifers also increases profitability through lower rearing costs with no adverse effect on productivity after calving. Conversely, animals with poor heifer fertility also had reduced survival and productivity and are thus unlikely to repay their rearing costs.

\section{ACKNOWLEDGEMENTS}

The authors thank the farm staff and veterinarians who contributed to this project. The work was co-funded by DairyCo and Defra. Manuscript number VBS_00407.

\section{REFERENCES}

[1] Tozer, P.R. and Heinrichs, A.J. (2001) What affects the costs of raising replacement dairy heifers: A multiplecomponent analysis. Journal of Dairy Science, 84, 18361844. doi:10.3168/jds.S0022-0302(01)74623-1

[2] Brickell, J.S., Bourne, N., McGowan, M.M. and Wathes, D.C. (2009) Effect of growth and development during the rearing period on the subsequent fertility of nulliparous Holstein-Friesian heifers. Theriogenology, 72, 408-416. doi:10.1016/j.theriogenology.2009.03.015

[3] Johnson, K., Burn, C.C. and Wathes, D.C. (2011) Rates and risk factors for contagious disease and mortality in young dairy heifers. $C A B$ Reviews, 6, No. 059.

[4] Pirlo, G., Miglior, F. and Speroni, M. (2000) Effect of age at first calving on production traits and on difference between milk returns and rearing costs in Italian Holsteins. Journal of Dairy Science, 83, 606-608. doi:10.3168/jds.S0022-0302(00)74919-8

[5] Mayne, C.S., McCoy, M.A., Lennox, S.D., Mackey, D.R., Verner, M., Catney, D.C., McCaughey, W.J., Wylie, A.R., Kennedy, B.W. and Gordon, F.J. (2002) Fertility of dairy cows in Northern Ireland. Veterinary Record, 150, 707713. doi:10.1136/vr.150.23.707

[6] Hare, E., Norman, H.D. and Wright, J.R. (2006) Trends in calving ages and calving intervals for dairy cattle breeds in the United States. Journal of Dairy Science, 89, 365370. doi:10.3168/jds.S0022-0302(06)72102-6

[7] Losinger, W.C. and Heinrichs, A.J. (1997) An analysis of age and body weight at first calving for Holsteins in the United States. Preventative Veterinary Medicine, 32, 193205. doi:10.1016/S0167-5877(97)00018-4

[8] Lin, C.Y., McAllister, A.J., Batra, T.R., Lee, A.J., Roy, G.L., Vesely, J.A., Wauthy, J.M. and Winter, K.A. (1986) Production and reproduction of early and late bred dairy heifers. Journal of Dairy Science, 69, 760-768. doi:10.3168/jds.S0022-0302(86)80465-9

[9] Ettema, J.F. and Santos, J.E.P. (2004) Impact of age at calving on lactation, reproduction, health, and income in first-parity Holsteins on commercial farms. Journal of Dairy Science, 87, 2730-2742.

doi:10.3168/jds.S0022-0302(04)73400-1
[10] Evans, R.D., Wallace, M., Garrick, D.J., Dillon, P., Berry, D.P. and Olori, V. (2006) Effects of calving age, breed fraction and month of calving on calving interval and survival across parities in Irish spring-calving dairy cows. Livestock Science, 100, 216-230. doi:10.1016/j.livprodsci.2005.09.003

[11] Keown, J.F. and Everett, R.W. (1986) Effect of days carried calf, days dry, and weight of first calf heifers on yield. Journal of Dairy Science, 69, 1891-1896. doi:10.3168/jds.S0022-0302(86)80615-4

[12] Hoffman, P.C. (1997) Optimum body size of Holstein replacement heifers. Journal of Animal Science, 75, 836845.

[13] Dawson, L.E.R. and Carson, A.F. (2004) Management of the dairy heifer. Cattle Practice, 12, 181-192.

[14] Mourits, M.C.M., Galligan, D.T., Dijkhuizen, A.A. and Huirne, R.B.M. (2000) Optimization of dairy heifer management decisions based on production conditions of Pennsylvania. Journal of Dairy Science, 83, 1989-1997. doi:10.3168/jds.S0022-0302(00)75076-4

[15] Serjsen, K. (2005) Mammary development. In: Garnsworthy, P.C., Ed., Calf and Heifer Rearing: Principles of Rearing the Modern Dairy Heifer from Calf to Calving, Nottingham University Press, Nottingham, 237-251.

[16] Van Amburgh, M.E., Galton, D.M., Bauman, D.E., Everett, R.W., Fox, D.G., Chase, L.E. and Erb, H.N. (1998) Effects of three prepubertal body growth rates on performance of Holstein heifers during first lactation. Journal of Dairy Science, 81, 527-538. doi:10.3168/jds.S0022-0302(98)75604-8

[17] Macdonald, K.A., Penno, J.W., Bryant, A.M. and Roche, J.R. (2005) Effect of feeding level pre- and post-puberty and body weight at first calving on growth, milk production, and fertility in grazing dairy cows. Journal of Dairy Science, 88, 3363-3375. doi: 10.3168/jds.S0022-0302(05)73020-4

[18] Sakaguchi, M., Suzuki, T., Sasamoto, Y., Takahashi, Y., Nishiura, A. and Aoki, M. (2005) Effects of first breeding age on the production and reproduction of Holstein heifers up to the third lactation. Animal Science Journal, 76, 419-426. doi:10.1111/j.1740-0929.2005.00285.x

[19] Esslemont, R.J. and Kossaibati, M.A. (1997) The cost of respiratory diseases in dairy heifer calves. The Bovine Practitioner, 33, 174-178.

[20] Brickell, J.S. and Wathes, D.C. (2011) A descriptive study of the survival of Holstein-Friesian heifers through to third calving on English dairy farms. Journal of Dairy Science, 94, 1831-1838. doi:10.3168/jds.2010-3710

[21] Simerl, N.A., Wilcox, C.J. and Thatcher, W.W. (1992) Postpartum performance of dairy heifers freshening at young ages. Journal of Dairy Science, 75, 590-595. doi:10.3168/jds.S0022-0302(92)77796-0

[22] Mee, J.F. (2008) Prevalence and risk factors for dystocia in dairy cattle: A review. Veterinary Journal, 176, 93-101. doi:10.1016/j.tvj1.2007.12.032

[23] Simerl, N.A., Wilcox, C.J., Thatcher, W.W. and Martin, F.G. (1991) Prepartum and peripartum reproductive performance of dairy heifers freshening at young ages. Jour- 
nal of Dairy Science, 74, 1724-1729. doi:10.3168/jds.S0022-0302(91)78335-5

[24] Shook, G.E. (2006) Major advances in determining appropriate selection goals. Journal of Dairy Science, 89, 1349-1361. doi:10.3168/jds.S0022-0302(06)72202-0

[25] Schneider, Mdel. P., Strandberg, E., Emanuelson, U., Grandinson, K. and Roth, A. (2007) The effect of veterinary-treated clinical mastitis and pregnancy status on culling in Swedish dairy cows. Preventative Veterinary Medicine, 80, 179-192.

doi:10.1016/j.prevetmed.2007.02.006

[26] Wu, J., Brickell, J.S., Yang, L.G., Cheng, Z., Zhao, H.Q., Wathes, D.C. and Zhang, S.J. (2012) Reproductive performance and survival of Chinese Holstein dairy cows. Animal Production Science, 52, 11-19. doi:10.1071/AN11146

[27] Bach, A. (2011) Associations between several aspects of heifer development and dairy cow survivability to second lactation. Journal of Dairy Science, 94, 1052-1057. doi:10.3168/jds.2010-3633

[28] Donovan, G.A., Bennett, F.L. and Springer, F.S. (2003) Factors associated with first service conception in artificially inseminated nulliparous Holstein heifers. Theriogenology, 60, 67-75. doi:10.1016/S0093-691X(02)01296-7

[29] Kuhn, M.T., Hutchison, J.L. and Wiggans, G.R. (2006) Characterization of Holstein heifer fertility in the United States. Journal of Dairy Science, 89, 4907-4920. doi:10.3168/jds.S0022-0302(06)72541-3

[30] Brickell, J.S., McGowan, M.M. and Wathes, D.C. (2009) Effect of management factors and blood metabolites during the rearing period on growth in dairy heifers on UK farms. Domestic Animal Endocrinology, 36, 67-81. doi:10.1016/j.domaniend.2008.10.005

[31] Donovan, G.A., Dohoo, I.R., Montgomery, D.M. and Bennett, F.L. (1998) Calf and disease factors affecting growth in female Holstein calves in Florida, USA. Preventative Veterinary Medicine, 33, 1-10. doi:10.1016/S0167-5877(97)00059-7

[32] Coffey, M.P., Hickey, J. and Brotherstone, S. (2006) Ge- netic aspects of growth of Holstein-Friesian dairy cows from birth to maturity. Journal of Dairy Science, 89, 322329. doi:10.3168/jds.S0022-0302(06)72097-5

[33] Wathes, D.C., Brickell, J.S., Bourne, N., Swali, A. and Cheng, Z. (2008) Factors influencing heifer survival and fertility on commercial dairy farms. Animal, 2, 1135-1143. doi:10.1017/S1751731108002322

[34] Thomson, J.R., Pollak, E.J. and Pelissier, C.L. (1983) Interrelationships of parturition problems, production of subsequent lactation, reproduction and age at first calving. Journal of Dairy Science, 66, 1119-1127. doi:10.3168/jds.S0022-0302(83)81909-2

[35] Johanson, J.M. and Berger, P.J. (2003) Birth weight as a predictor of calving ease and perinatal mortality in Holstein cattle. Journal of Dairy Science, 86, 3745-3755. doi:10.3168/jds.S0022-0302(03)73981-2

[36] Hansen, M. (2004) Quantitative genetic analysis of mortality in Danish Holstein calves. Ph.D. Thesis, Royal Veterinary and Agricultural University, Copenhagen.

[37] Brickell, J.S., McGowan, M.M., Pfeiffer, D.U. and Wathes, D.C. (2009) Mortality in Holstein-Friesian calves and replacement heifers in relation to body weight and IGF-I concentration, on 19 farms in England. Animal, 3, 1175-1182. doi:10.1017/S175173110900456X

[38] Lin, C.Y., McAllister, A.J., Batra, T.R., Lee, A.J., Roy, G.L., Vesely, J.A., Wauthy, J.M. and Winter, K.A. (1988) Effects of early and late breeding of heifers on multiple lactation performance of dairy cows. Journal of Dairy Science, 71, 2735-2743. doi:10.3168/jds.S0022-0302(88)79867-7

[39] Nilforooshan, M.A. and Edriss, M.A. (2004) Effect of age at first calving on some productivity and longevity traits in Iranian Holsteins of the Isfahan province. Journal of Dairy Science, 87, 2130-2135. doi:10.3168/jds.S0022-0302(04)70032-6

[40] Hultgren, J. and Svensson, C. (2009) Heifer rearing conditions affect length of productive life in Swedish dairy cows. Preventative Veterinary Medicine, 89, 255-264. doi:10.1016/j.prevetmed.2009.02.012 